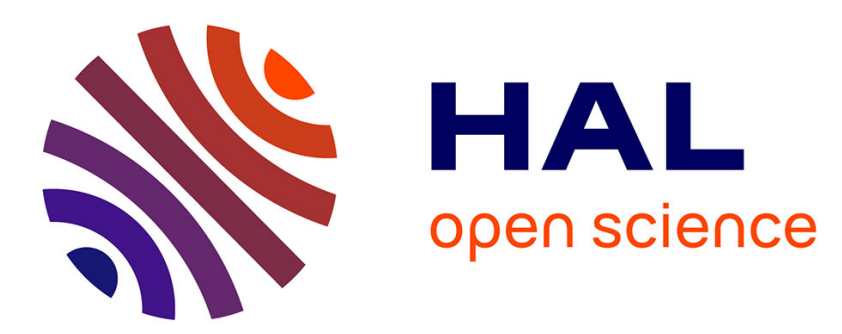

\title{
Biology teachers designing context-based lessons for their classroom practice - the importance of rules-of-thumb
}

Nienke Wieringa, Fred Janssen, Jan van Driel

\section{- To cite this version:}

Nienke Wieringa, Fred Janssen, Jan van Driel. Biology teachers designing context-based lessons for their classroom practice - the importance of rules-of-thumb. International Journal of Science Education, 2011, 10.1080/09500693.2011.553969 . hal-00692181

\section{HAL Id: hal-00692181 \\ https://hal.science/hal-00692181}

Submitted on 29 Apr 2012

HAL is a multi-disciplinary open access archive for the deposit and dissemination of scientific research documents, whether they are published or not. The documents may come from teaching and research institutions in France or abroad, or from public or private research centers.
L'archive ouverte pluridisciplinaire HAL, est destinée au dépôt et à la diffusion de documents scientifiques de niveau recherche, publiés ou non, émanant des établissements d'enseignement et de recherche français ou étrangers, des laboratoires publics ou privés. 


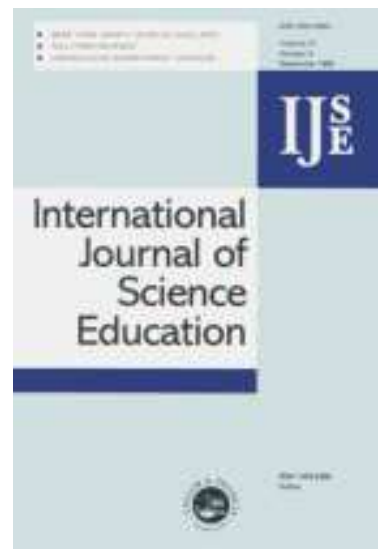

\section{Biology teachers designing context-based lessons for their classroom practice - the importance of rules-of-thumb}

\begin{tabular}{|r|l|}
\hline Journal: & International Journal of Science Education \\
\hline Manuscript ID: & TSED-2010-0142.R1 \\
\hline Manuscript Type: & Research Paper \\
\hline Keywords : & context-based education, lesson design, teacher knowledge \\
\hline Keywords (user): & curriculum innovation, teacher development, biology education \\
\hline \multicolumn{2}{|l}{} \\
\hline
\end{tabular}

\section{SCHOLARONE" Manuscripts}




\title{
Biology teachers designing context-based lessons for their classroom practice - the importance of rules-of-thumb
}

\begin{abstract}
In science education in the Netherlands new, context-based, curricula are being developed. As in any innovation, the outcome will largely depend on the teachers who design and implement lessons. Central to the study presented here is the idea that teachers, when designing lessons, use rules-of-thumb: notions of what a lesson should look like if certain classroom outcomes are to be reached. Our study aimed at (1) identifying the rules-of-thumb biology teachers use when designing context-based lessons for their own classroom practice, and (2) assessing how these personal rules-of-thumb relate to formal innovative goals and lesson characteristics. Six biology teachers with varying backgrounds designed and implemented a lesson or series of lessons for their own practice, while thinking aloud. We interviewed the teachers, and observed their lessons. Our results suggest that rules-of-thumb, which differed substantially among the teachers, indeed to a great extent guide the decisions teachers make when designing (innovative) lessons. These rules-of-thumb were often strongly associated with intended lesson outcomes. Also, teachers' personal rules-of-thumb were more powerful in determining the lesson design than formal innovative goals and lesson characteristics. The results of this study encourage more research into how rules-of-thumb reflect teachers' practical knowledge, for which suggestions are made.
\end{abstract}




\section{Introduction}

There is an international trend in science education towards context-based approaches. Teaching concepts in relationship to real-world contexts is expected to make science education more meaningful, relevant and motivating for students (Gilbert, 2006). In biology education in the Netherlands an innovation process towards context-based education is currently taking place (Boersma et al, 2007). As in any innovation the outcome will largely depend on the teachers implementing it (Fullan, 2007; Van Driel, Beijaard, \& Verloop, 2001).

Teachers generally do not implement an innovation exactly the way it was originally envisioned and described in curriculum documents (Fullan, 2004). Research has shown that when teachers interpret an innovation their practical knowledge, which is an integration of experiential knowledge, formal knowledge and personal beliefs acts as a filter (Levin \& He, 2008; Van Driel et al., 2001). Moreover, knowing that innovations are often poorly translated into teaching materials (Van Berkel, 2005), teachers frequently need to design innovative lessons themselves. Although many authors have pointed to the importance of studying teachers' instructional design in order to understand how practical knowledge informs instructional decision making (Clark \& Dunn, 1991; Hashweh, 2005; Sanchez \& Valcarcel, 1999), this relationship has scarcely been subject to research (Hashweh, 2005). Therefore, in this study we explore the role of teachers' practical knowledge in their design of innovative context-based lessons for their own classroom practice.

\section{Theory}

\section{Context-based biology education}

Context-based education is not new. It has been propagated in different parts of the world, in slightly different forms and with different purposes, often in response to alleged failures of the 
traditional science curriculum (Aikenhead, 2007; Gilbert, 2006). Likewise, context-based education is seen as a possible answer to the problems in biology education in The Netherlands that were identified by the Royal Netherlands Academy of Arts and Sciences in their 2003 report (KNAW, 2003): a lack of relevance (from the viewpoint of both students and of science and society), a lack of coherence (between biological concepts and between concepts and contexts), and an overload of biological concepts in the curriculum.

When reviewing the international literature on context-based education, one has to conclude that besides providing an answer to these problems there are many other objectives to be obtained by context-based education. Most importantly, context-based education is expected to improve students' understanding: contexts are thought to trigger students' preconceptions, which are the starting point for meaningful learning (Scott, Asoko, \& Leach, 2007). This is further stimulated by the use of questions and problems from real-world contexts as starting points for developing a 'need' to learn about scientific concepts (Bulte, Westbroek, de Jong, \& Pilot, 2006). Second, context-based education is thought to increase coherence within curricula, because various concepts come together within contexts and reappear in other contexts (Gilbert, 2006; Pilot \& Bulte, 2006). Third, context-based education is expected to increase student motivation more effectively than more traditional educational approaches, and make students feel more positive about science (Bennett, Lubben, \& Hogarth, 2007). Context-based education is also used to change the educational emphasis from learning scientific "facts" to involving students in scientific activities such as argumentation, modelling, and designing (Krajcik, McNeill, \& Reiser, 2008), and more in general of increasing the relevance of the science curriculum by embedding concepts within relevant contexts and using relevant contexts to select the scientific concepts and skills to be learnt (Boersma et al., 2007).

In the same way as there are various, often related, reasons for using contexts in science education, there are many different ideas about how to define "context" in education and what a "context-based lesson" should look like. A "context" has been alternately described as a theme, 
issue, story, topic, situation, practice, application and problem (Bennett, Grasel, Parchmann, \& Waddington, 2005; Goedhart, 2004; Pilot \& Bulte, 2006). Of these, the interpretation used most frequently is that of a context as a "situation". The type of situation chosen also varies. Some authors only select situations that are of personal relevance to students (Taasoobshirazi \& Carr, 2008), or have societal relevance (Zeidler, Sadler, Simmons, \& Howes, 2005), whereas others include all contexts that students may encounter in their personal or future professional life, or may help them understand how science "works" (Aikenhead, 2007). For our purposes we have chosen to define a context as a realistic situation from students' own lives, from society or from professional or scientific practices.

Although opinions on the definitions and goals of context-based education differ, there seem to be some basic characteristics of context-based lessons that many people agree upon, which in this study will be called the formal design principles (Figure 1). A context-based lesson or lesson sequence typically starts with an introductory phase, during which students can imagine themselves being part of the situation (Bennett et al., 2007). From this situation a question or problem arises logically. Students answer this question by performing learning activities, meanwhile gaining insight into the biological concepts that are needed to answer the question or solving the problem (Bennett et al., 2007; Bulte et al., 2006; Glynn \& Koballa, 2005; Kortland, 2007). In the end reflection on the process takes place, the answers are summarized and explicit attention is given to the biological concepts used. This procedure is expected to enable transfer of these concepts to new contexts (recontextualization; Van Oers, 1998).

- $\quad$ insert Figure 1 about here -

\section{Teachers' personal rules-of-thumb}

Many authors have pointed out that teachers generally do not implement an innovation in the way it was originally envisioned. Innovations are interpreted, with teachers' personal practical 
knowledge playing an important role. 'Practical knowledge' is defined as the cognitions that underlie teachers' actions (Meijer, 1999). Hashweh (2005) informs us that this practical knowledge 'results initially, and most importantly, from teacher planning, which is essentially a design process' (p. 278). He adds that the relation between lesson design and a teacher's practical knowledge is a reciprocal one: teachers draw on their knowledge when deciding on instructional goals and strategies. Still, as yet little research has been conducted on the manner in which practical knowledge informs teachers' decision making during lesson planning.

We might learn from descriptive studies into teacher lesson planning that have been carried out in the past. Until the 1970s the main aim of these studies was to describe teacher behaviour and to assess whether teachers follow formal planning models - the conclusion was that they usually don't (Yinger \& Hendricks-Lee, 1994). From the 1970s onward, attention shifted to teachers' cognitions. Lesson planning was considered a process of either solving problems or decision making, in which teachers generate alternatives and choose between them (Shavelson, 1973). This perspective has been criticized, because it underestimates the role of routines and the influence of classroom materials (Clark \& Dunn, 1991; Shavelson \& Stern, 1981). The image of the teacher as a rational decision maker evolved into the image of the reasonable decision maker, who makes judgments and decisions in a complex and uncertain environment. Instead of balancing multiple alternatives when designing their lessons, teachers seem to be guided by a limited set of rules-of-thumb developed during the process of planning, teaching and reflecting. Such rules-of-thumb are defined as prescriptive notions of advisable lesson characteristics, most often related to some intended outcomes in student understanding, student behaviour, student and teacher emotions and lesson organization (Elbaz, 1983; Feldman, 2000; Janssen, Veldman, \& Van Tartwijk, 2008; Peters \& Beijaard, 1983).

This study set out to explore six biology teachers' decision making processes when designing innovative context-based biology lessons for their own educational practice. We expected the outcome of these processes to be determined by both teachers' personal rules-of-thumb and 
their appreciation of the innovative goals and lesson characteristics. This has led to the following research questions:

(1) What rules-of-thumb do biology teachers use when designing context-based lessons for their own educational practice?

(2) How do these personal rules-of-thumb relate to the formal innovative goals and lesson characteristics?

In other words, we wished to explore the applicability of the concept of rules-of-thumb in a study of innovative lesson design by teachers, while at the same time learning how teachers interpret the idea of context-based biology education when designing lessons.

\section{Methods}

\section{Selection of participants}

Because the context-based innovation of the Dutch biology curriculum is meant to be implemented by teachers of varying levels of experience and with different teaching styles, and on different grade levels, we aimed to include a variety of secondary school biology teachers teaching a range of grade levels at different school types in this study. We sought advice from two experts with a wide network of biology teachers, which resulted in our contacting fourteen biology teachers. Six of them agreed to participate; they all teach at different Dutch city schools. Table 1 summarizes participant characteristics. Both David and Vera (not their real names) are experienced designers of context-based lessons: David because he had already been involved in the design of an experimental context-based curriculum since three years and Vera because she had been using contexts in her lessons for several years, independently from the current innovation in biology education. None of the teachers had, before the start of the study, experienced any professional development activities aimed at designing or implementing contextbased biology education, with the exception of David, who had been participating in a teacher 


\section{Data collection}

We asked every teacher to design a context-based lesson or short lesson sequence of three lessons at most for one of their own classes. Given the design of this study we did not want teachers to design large lesson modules and sophisticated materials. Rather, we wished to observe teachers' day-to-day design activities, the only difference being that this time they would follow a context-based approach. During the implementation phase of the innovative biology curriculum in the Netherlands teachers will not be obliged to follow a professional development programme. An 'average' Dutch biology teacher is expected to learn about the context-based approach in some way or another, but a majority of teachers is not going to follow an extensive professional development programme. Hence, we did not train the teachers in designing contextbased lessons, but only informed them about the definition of context-based education and the formal design principles used in this study (Figure 1), and the general aims of context-based education: increasing relevance, student understanding, conceptual coherence and student motivation. This was done by means of a short note $(1 \mathrm{~A} 4)$ and a very short oral introduction during the first interview. Additionally, we provided the teachers with a modest literature package that represented the literature about context-based education that was easily available to teachers at that moment: the 2007 report of the Dutch Biology Education Innovation Committee (CVBO) (Boersma et al., 2007), and five articles from Dutch science education journals (Lijnse, 2007; Schalk \& De Hullu, 2007; Van den Oever, 2007; Vermaat, 2007; Wolter \& Van Woerkom, 2007). 
After a short, structured interview, intended to gather information about the teacher's background, teaching experience and knowledge and beliefs concerning context-based education, teacher and researcher together decided for which class and date to design a lesson, on the basis of two criteria: (1) ecological validity: the teachers designed a lesson that they would normally also have been planning at that moment. For Kate, Richard, Thomas and Vera, this meant they designed a lesson they planned to teach one or a few days later, because they usually plan their lessons only a short time ahead, while David and Marion designed a lesson they planned to teach a month later, because they usually plan their lessons at the beginning of a new term; and (2) teachers' preferences: sometimes teachers had specific reasons for choosing a particular class or moment, for example because the subject was considered difficult and they hoped the new approach would lead to better student understanding.

Immediately after this interview participants designed their context-based lesson, while thinking aloud. We asked the teachers to use the formal design principles (Figure 1) as a starting point. They were free to use all the materials they wanted. The teachers designed their lesson in the same surroundings as where they would normally design their lessons (that is: at school, in an office or at home) and were instructed to use the same procedures they would normally use. The design activities the teachers undertook were manifold: studying the school book, searching the internet (fora, encyclopaedic sites, news sites, scientific articles, video material), searching own databases, brainstorming on a piece of paper, specifying learning goals, envisioning student activities in the classroom, elaborating student worksheets, arranging practical necessities such as making classroom reservations, etcetera. The amount of time spent on designing was not limited by the researcher. In practice, the entire design session lasted between 40 and 70 minutes.

During the lesson design process the first author was present. She generally did not Deleted: the researcher intervene, except for asking 'what are you thinking right now?' The teachers in our study reported that they experienced the design process while thinking aloud as similar to the natural situation, although Richard said he now spent slightly more time designing the lesson than he would 


\section{Data analysis}

The first step in the analysis was to identify all decisions made by the teachers during the design process. Design decisions could be diverse, e.g., choice of student activities ('I want to use a creative activity'), choice of organisation ('this time, students don't work in groups, but individually'), or a choice not to do something that had been considered ('I don't choose the holiday context, because...' (Kate)). Design decisions taken before the lesson could easily be

normally do. Both Thomas and Marion said the situation felt slightly uncomfortable, although they did not think this influenced their thinking processes very much. Following the thinkingaloud session, we asked the teachers to reflect on the design process, to clarify decisions made, and to explain what factors hindered or promoted the design of the lesson. Of all thinking-aloud sessions and interviews audio and video recordings were made, and all interviews and thinkingaloud protocols were typed out verbatim.

Following Clark \& Peterson (1986) we understand the lesson design process as a cyclic process of planning, implementation and reflection. This means that we expected design decisions not only to be taken during the thinking aloud session, which resulted in a lesson plan, but also between the thinking aloud session and the implementation of the lesson and during the implementation of the lesson. All teachers had drawn up the basic structure of the lesson within the thinking-aloud session, but most teachers indeed also performed some supplementary design activities between the session and the implementation of the lesson in the classroom, such as drawing up student assignments in more detail and making practical arrangements. The teachers kept notes of all these activities. The lesson itself was observed and videotaped. During the observations of the lessons, the researchers drew up description of the lesson, in which both students' and teacher's activities were noted as well as the time at which they were taking place. Following it, an interview was held in which the initial findings were presented to the teacher, and the teachers were asked to further clarify the decisions they had made.

Deleted: The lesson design process, normally, is a cyclic process of planning, implementation and reflection. Design decisions can be taken during the thinking aloud session, which resulted in a lesson plan, but also between the thinking aloud session and the implementation of the lesson and during the implementation of the lesson. In this study, however, most design decisions appeared to be taken during the thinking-aloud session, after which most teachers adapted the lesson plan only at a detailed level (with the exception of Thomas, as we will explain later). The following data sources were used to identify the teachers' design decisions: $\mathrm{t} ; \boldsymbol{9}$ - the lesson observation protocols; the typed-out interviews

Deleted: . During the observations of the lessons, the researchers drew up a protocol of the lesson, in which both students' and teacher's activities were noted as well as the time at which they were taking place. Next to this protocol, their was space for the researchers to make their own observations. Then, the teachers' own lesson plans were used to compare the planned lesson structure and activities with the implemented lesson. Discrepancies

could be traced back to decisions made just before or during the lesson. 
identified using the protocols and teachers' notes. Decisions taken during the lesson were identified by comparing the teachers' own lesson plans with the summary of the implemented lesson. Discrepancies could be traced back to decisions made just before or during the lesson, which were confirmed or explained by the teachers during the interview following the lesson.

Every decision was linked to the reasons that particular teacher gave for making that choice. Often, these reasons would be obvious from the thinking-aloud protocol (e.g. 'So, that's playing blind man's buff, just to let them experience it, that is just a funny intro, that will be fun' (Thomas)). If the reason for a certain decision was unclear, we asked the teacher for clarification immediately after the thinking-aloud session. Based on this information, the first author drew up a summary of decisions and reasons for each of the six teachers. As a first member check, we presented this summary to the teachers during the post-lesson interview, and asked them to confirm and/or adapt it. No major adaptations appeared necessary. This process resulted in a decision summary, an example of which is given in the Appendix. The decision summaries were used by two researchers independently from each other to identify all personal rules-of-thumb and related intended outcomes that influenced the design process. They tried to keep as close to the teacher's own phrasing as possible. There were some minor differences between the two researchers, which could all be easily resolved through discussion. Ultimately, we used a second member check to validate the findings: we sent the tables of rules-of-thumb and intended outcomes, plus the narratives as they appear in the Results section of this paper, to the teachers, who confirmed that their personal reasoning had been correctly and recognizably represented in the text and Tables. One teacher asked us to rephrase one rule-of-thumb, which we did, after reviewing the original data.

In short, we tried to validate the data by triangulation of data source and method (interviews, thinking-aloud protocols, video analyses), by triangulation of researchers, and by using member checks (Miles \& Huberman, 1994). We tried to optimize the ecological validity of the findings by visiting the teachers in their own school environment and asking them to design 
and implement a lesson in the way they would normally do it. The validity of the rules-of-thumb that will be presented in the next section may be limited to the particular levels and subjects of those lessons. However, teachers' phrasings suggest a more general validity, as was confirmed by their concluding email messages (e.g. Vera: 'You have understood and represented me and my ideas about teaching very well.')

\section{Results}

In this section we will describe the individual teachers' decision making processes and link these to their personal rules-of-thumb and, if the link could be established from the data, intended lesson outcomes associated with these rules-of-thumb (table 2). In the representation of the teachers' reasoning and rules-of-thumb in this article we have kept as close to the teachers' own phrasings as possible. As a consequence, the rules-of-thumb as they appear in this study are dissimilar in shape and level of abstraction.

\section{Kate (pre-university education, 12/13 yrs old): Biodiversity in a park}

During the first interview it was immediately obvious that during her years of teaching experience Kate had given a lot of thought to her educational goals. She made extensive use of personal rules-of-thumb when designing the lesson (Table 2). The intended outcome for most of these principles comes down to one thing: better student understanding of biological concepts. During the post-lesson interview Kate formulated the ultimate goal of her lessons: she wants her students to be able to recognize biology in the real world while thinking like a biologist, not like a park designer or a doctor: 'In my lesson you [the student] are a biologist, you think like a biologist'. At the same time she considered the emotional well-being of her students, again in order to facilitate learning: 'When the group atmosphere is good and students believe they can succeed, they learn best'. This is also the source of most of her rules-of-thumb: these all are ideas of what lessons should look like, in order to further student understanding in the best way possible. One example is to start from the biological concepts, not from a context, because 
otherwise they cannot know from what angle to think; it is about biology, not about economy. From an economic point of view dog dirt on the lawn might also be a problem, but then you should find a different solution'. Contexts, in Kate's opinion, first of all serve to give meaning to concepts by triggering preconceptions and helping students understand what the concept means in their own situation, thus enabling conceptual development from a constructivist point of view, and eventually application of the concepts in reality.

Kate's lesson started with a question central to biology, namely: What does an animal need to be able to survive and reproduce? Kate aimed to have students understand the meaning of this question by letting them draw their own house and identify elements of their surroundings they really need, like food, safety, a pleasant room temperature, etc. This is what Kate called the main "context" of her context-based lesson. After drawing their own house, students drew the "house" of an animal they knew from a recent park visit. For this purpose, Kate had prepared 27 different biographies of the animals involved. She had also brought a map of an imaginary park that students could use to find a home for "their" animals. This moment in the lesson led to emotional scenes: 'There is no place my frog can live! There is no pond in the park!' After deliberation, the teacher and students resolved this by adapting the park in such a way that every animal could have its place in it. During the lesson, the students regularly referred to their textbooks so that they could link classroom activities to the concepts used in the book: habitat, nature development and biodiversity.

During the interview following the lesson, Kate recalled that some students had found it very difficult to understand why they had to draw their own house. We came to discuss the fact that the lesson could have taken another shape, more in line with the formal principles, according to which the design of a park would have been the start of the lesson and students would have had the role of park designers. The question then would have been something like: "how can we make a park where many animals can find what they need to survive and reproduce?” Kate clearly showed her disapproval of the idea: 'When you ask them to design a park, I feel you are cheating 
them... because they will never be permitted to design a park for real... that is no good. The question is even, if somebody says: "student, help me design this park", if that will be taken seriously... I'm afraid it will not. I do not want to do that to them... It almost makes me sad.'

The basic structure of the lesson was finished within the thinking-aloud session, but making the lesson took Kate eight hours in all, which she mainly spent on writing the biographies, making the student worksheets and drawing the park map. Kate was very satisfied with the resulting lesson; it was quite different from her regular lessons, which usually start with her writing a definition on the board, explaining the definition, giving examples, followed by having the students make exercises from their textbooks.

\section{Richard (upper general secondary education, 15/16 yrs old): A safari trip}

Richard has been a teacher for six years, after working as an IT-specialist for a time. His main concern as a teacher was a lack of student motivation, which he hoped to address through the implementation of context-based education.

When designing the lesson, Richard started by determining the concepts to be learnt: the structure and function of the autonomous nervous system. He then began an internet search using the search terms 'autonomous nervous system' and 'disease'. In this way he gathered many ideas for the context for this lesson: asthma, bowel diseases, prion diseases, and so on. However, he rejected all these ideas, because he thought they would not lead to the idea that the autonomous nervous system affects all organs at the same time. What is more, he was afraid that using a medical context would give students the impression that things in their body go wrong all the time, while he'd rather have them imagine how well everything is organized inside them. At this point Richard got stuck. He sighed: 'All the time, it's only one organ, and that doesn't fit the material to be learnt. If we wouldn't try so hard to make some context-based thing, I would have stopped a long time ago... What can it be, something that appeals to them and helps them to remember...?
Deleted: <\#>insert Table 2 about here -9 
That is when he thought about his regular way of teaching the subject, using the analogies of the lion (when a lion jumps forward at you, your nervous system is in a state of arousal, and it happens to be a handy mnemonic that a ganglion is a structural characteristic of that system) and a cake-eating event, when the system is in a state of rest. Normally, he simply explains to the students, using these analogies, what the structure of the nervous system is and how it works, after which the students work from their books. He says: 'Well, yeah, of course we could ... change the student activity, because, of course, in the end, the context simply is your own body and what it should do in different situations.... And that's how I normally explain it to them, but of course I could do it by not explaining it [but] by stimulating the students to think for themselves about what, in situation 1 and situation 2, the organs should do.'

Now the lesson took shape very quickly: it started with a gripping story about the class being on a safari trip, celebrating the birthday of one of the students, eating cake, when suddenly a lion jumped out while the guide was distracted by the new gadgets on his cell phone. The questions that followed were: "what should your organs be doing in the cake-eating situation? And what should they do when the lion appears on stage?" Without needing more information the students were able to figure out what the answers to these questions should be, after which the teacher explained how the autonomous nervous system is designed to make sure the organs are in fact doing what the students predicted they should be doing.

Afterwards, Richard thought this was a good context-based lesson, and actually better than his regular ones. He realized that the student activities in this lesson did not at all resemble what you would actually do in the context given (it would be very foolish to ponder on the state of your kidneys while you are being attacked by a lion), but he did not consider that problematic, for the context served to motivate students, stimulate them into action, and give them something to help them remember the concepts. The lesson would not gain in relevance if an understanding of the concepts would really be necessary in some situation or another. According to Richard, conceptual understanding is relevant in itself. 


\section{Thomas (upper general secondary education, $12 / 13$ yrs old): Vision impairments}

Thomas is in his first year of teaching. He is a passionate collector of "amazing biological stories". Anecdotes from newspapers or television shows have a prominent place in his lessons. For Thomas, the main reason for participating in this research was his general willingness to 
innovate, but from the beginning he had been sceptical towards the assumptions underlying the current innovation. He felt that most of the contexts that feature as examples in official documents would not motivate students to learn and teachers to teach. Thomas considered it very important to give original, fun lessons, with students and teacher sharing their experiences. Most of his regular lessons have the following structure: start with a newspaper article, then give a clear explanation of the concepts to be learnt, after which students make exercises from the book, and end the lesson with an instructive video fragment.

While designing his context-based lesson Thomas spent a lot of time searching for a context that was interesting enough to spend a whole lesson on and at the same time covered the concepts to be learned. This process quickly frustrated him, because he felt he did not succeed in finding a context for which it would be necessary to understand the function of every part of the eye, which was the concept to be taught in this lesson. Therefore, Thomas changed his strategy and started thinking of an activity that covered the concepts (making a drawing of an eye with a certain defect), which helped him to select a context to fit this activity (making an illustration for a medical handbook). Interestingly enough, Thomas forgot to mention this altogether during the lesson itself, showing that he did not consider this particular context essential to the lesson. The lesson started with a discussion of a newspaper article about colour-blind monkeys, which naturally resulted in a discussion of vision impairments in general, after which students made drawings to illustrate these vision impairments.

Thomas's feelings after the lesson were mixed: he was happy with the interactive discussions, and his students expressed their appreciation for the lesson, but he thought the "main activity" of drawing the eye was a bit boring, whereas the students did not understand very well what they were supposed to do and learn. 


\section{David (Pre-university education, 15/16 yrs old): Cell differentiation during embryonic} development

David is an enthusiastic biology teacher and teacher educator who has some years' experience in developing context-based lesson sequences. The lesson he designed was part of a larger sequence about love, sex and reproduction. In his long-term plan, already made, he had determined the concepts to be learnt per lesson and the materials he had to offer. In this way it had already been decided that this lesson would cover hox genes and cell differentiation in embryos, and that a film about cell migration in a zebra fish embryo should be shown. During the thinking-aloud session David used many other rules-of-thumb to make up the rest of the lesson, while he explicitly linked every rule to objectives to be reached (see Table 2). The resulting lesson was built around the central question: What is happening at cellular level during embryonic development? Many examples ("contexts") were used to illuminate the answer to this question in different situations. In this case the contexts mainly served to give meaning to the question and concepts, and to show an example of current biological research. The central question and its answer in different contexts were presented by David using lots of visually fascinating examples (scientific research into zebra fish embryo development, causes of growth disorders, a pregnant woman growing a beard, etc.), while the students mainly sat and listened, with the exception of two short moments when the students were asked to answer a question on paper.

Retrospectively, David thought this was a good context-based lesson, because he showed many examples and showed the dynamics of what's going on inside organisms.

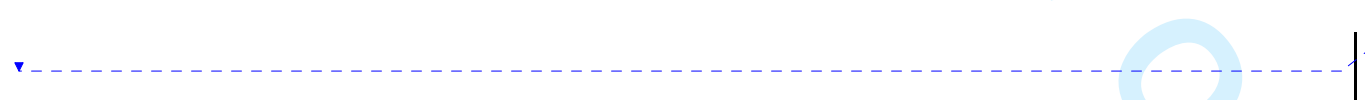

\section{Vera (pre-vocational secondary education, 13/14 yrs old): DNA in a personal context}

Vera started her teaching career as a nurse and medical teacher in the Israeli army. After migrating to the Netherlands she started a beauty salon, which at the time of the study she had 
for four years been combining with teaching external care and biology at a vocational secondary school.

During the interviews Vera explained that storytelling is a very important ingredient of her lessons. Those stories can sometimes be considered contexts in which biological concepts play a role, and sometimes they merely serve as metaphors, for example when she compares the circulatory system to the railways or the nervous system to a bread factory where orders are given from higher to lower hierarchical levels. Often, she does not prepare her lessons, choosing an improvisational approach instead, responding to the stories students bring to the classroom or the ideas that come into her mind during the lesson.

Vera's main goal for this particular lesson was to have her students realize the societal and personal importance of DNA knowledge. For this reason, Vera chose to start the lesson by telling her students a very personal story in an interactive way. Vera has a son with haemophilia, which is a genetic disease. She told her students how this had been discovered, and asked them what they thought it would mean to her son to have this disease (referring back to another concept domain: circulation). Then she explained that she herself appeared to be the carrier. She asked her students to help her explain what a "carrier" is and what that has to do with DNA and

chromosomes. Subsequently, she gave her students a pile of newspaper articles on a wide range of DNA -related topics, and a very open assignment to choose a subject, search the internet and make a PowerPoint presentation about DNA. Vera was the only teacher of the six who did not determine the concepts to be learnt beforehand. She considered it more important for her students to realize the importance of the biological domain of genetics for society and people's personal lives, and left her students fairly free to determine what they wanted to investigate.

Reflecting on her lesson, Vera said it would have been better to have a more structured assignment, but in general she likes her students to have room to decide what and how they want to learn, and have them learn from their own experiences and questions. 


\section{Teachers' use of rules-of-thumb when they design context-based lessons}

The rules-of-thumb the individual teachers used when designing their context-based lessons have been summarized in the Results section. As will later be discussed in more depth, teachers' rulesof-thumb are personal and are likely to be linked to specific classes, subjects and contexts. Still, it is both possible and interesting to have a look at the whole of rules-of-thumb used by the teachers in this study, which are related to the choice of concepts, context and activities, respectively, All the teachers appeared to follow roughly the same process when designing the lesson: first, the concepts were determined, after which was decided which context to use, and as a last step the students' activities were developed. For all teachers, the unit plan they had made at the beginning of the term defined the concepts to be taken as starting points in the design of the lesson, which is in accordance with the observation by Clark \& Peterson (1986) that unit planning was considered the most important type of planning by teachers, followed by weekly and daily planning. Only after the concepts to be learnt had been established, attention was given to possible contexts for the lesson(s). The exception here was Vera, who was not very strict in her longer term planning. All teachers stressed that the context chosen should be appealing, in order

Deleted: Each teachers' individual set of rules-of-thumb seem to be a good representation of the manner in which these teachers' personal practical theories influence their decision making while designing lessons, as has been confirmed by the teachers themselves. In summary: $<\#>$ Kate's efforts were all focused on furthering students' understanding of biological concepts, with the ultimate aim of having students think like biologists when considering real-world situations. She worked towards these goals by giving her lessons the following properties: start from the concepts, use the textbook, and use examples from the students' own lives to give meaning to the biological concepts. $<\#>$ Richard mainly focused on activating his students, and giving them tools to help them to remember the lesson content. It was also very important for him that students were given a positive image of biology. Important rules-of-thumb were: use a simple and appealing context, stimulate students to find knowledge themselves, while offering tools that help students to remember the facts. I $<\#>$ Marion's main educational principle was not defined at the level of one lesson, but at the level of a longer sequence of lessons. Her main rule-of-thumb implied offering her students a large variety of learning activities, in order to cater for students with different learning styles. She considered context-based education another new asset within her repertoire. Thomas seened to be focused mainly on making enjoyable and original lessons from the book. There were no strong links from the book. There were no strong links
between his rules-of-thumb and intended between his rules-of-thumb and intended
lesson outcomes, which might be explained by the fact that he was still in his first year of teaching.

$<\#>$ David's lesson had many objectives: having his students develop a firm

understanding of the biological concepts while experiencing feelings of wonder, becoming more competent in using biological handbooks, understanding how science affects society and their view of the world, and realizing how they personally relate to the scientific story while at the relate to the scientific story while at the
same time learning about specific contexts. During the design of the lesson $\mathrm{Da}$

\section{Deleted: $\uparrow$}


to motivate students for the lesson. Two teachers (Richard, Marion) aimed at having one overall context for the lesson, while the other teachers had their students shift between different contexts. For three teachers (Richard, Marion and Thomas) it was essential for the context(s) not to be too complicated, for characteristics of the context were not to distract their students from learning the concepts they should learn, while the other three teachers considered both the concepts and context-specific information to be interesting and instructive. It would have been logical and in line with the innovation if the next step for the teachers would have been to design student activities to match the context, but often, teachers had other, conflicting, rules that determined the form the student activities should take, such as using activities that motivate students, that proved to be successful in former lessons, or that have students reinvent the concepts themselves, as will be elaborated in more depth in the following section.

Many rules-of-thumb used by the teachers seem to be strongly related to the nature of their educational aims: whether that be conceptual learning (Kate, David, Marion), factual learning (Richard, Thomas), affective aims such as attaining positive feelings towards biology or wonder about nature (Richard, David, Thomas) and personal and societal aims (Vera).

\section{Relation between teachers' rules-of-thumb and formal design principles}

While all six teachers succeeded in designing a context-based lesson according to their own standards, most chose not to adopt the formal design principles completely. We will try to explain this by exploring the teachers' intended outcomes for the lessons, and the rules-of-thumb they employed to generate these outcomes.

According to the formal principles the use of real-life situations in biology education is thought to increase relevance, student understanding, coherence and student motivation. Teachers' reasoning in this study showed that their personal rules-of-thumb conflicted with these ideas in several ways. First and most importantly, it was thought that a context which is too specific and realistic would not motivate students to learn, while increasing student motivation

Deleted: Four teachers aimed to include 'real' materials, such as video fragments or newspaper articles, either because they fit the objective of helping students recognize biology in the real world (Kate, Marion, Daniel), or simply because video fragments are a fun element of the lesson (Thomas). David, Kate and Richard stressed the importance of choosing a context at the level of the organism, because that is what students can relate to. From there it is possible to zoom in on the cellular and molecular levels (David), or zoom out to the ecosystem level (Kate). Kate, Richard and Vera had a preference for contexts

from students' own lives, which helps them to give meaning to the concepts and, the other way round, to recognize the concepts in their own environment. To further the relevance of the lesson for students, both Thomas and Vera liked to be flexible when implementing their lesson, giving students room to contribute and pose their own questions, unlike David who explicitly said: There are soft subjects, for which I give them more room... but this is hard biology $\ldots$ and I want to get on to that [zebra fish] film. 
was the teachers' foremost reason for using a context-based approach. One reason cited is that using such contexts would decrease the relevance of the curriculum in the eyes of the students: 'Why should I know what a mussel grower needs to know? I will never be a mussel grower!' (Thomas). Most teachers in this study did not use the context-based approach to increase the relevance of the curriculum, because they consider that covering the examination standards is relevant in itself. Vera was the only one who used her contexts to select concepts to be learnt, in order to increase the relevance of these concepts for students.

Interestingly, only David and Vera, who were the two teachers most experienced in designing and enacting context-based lessons, said they chose their contexts in such a way as to allow making connections between different biological themes or between different lessons, in order to help their students develop their understanding of the coherence between various biological themes. Vera's haemophilia context, for example, connected genetics with circulation. In contrast, Thomas and Richard explicitly tried to avoid such contexts, saying concepts should be put into a clear framework, and that they wished to prevent possible confusion caused by using concepts from different domains within one context.

In summary, the teachers in this study did not feel that the use of authentic, complex contexts would help them work towards the outcomes they intended their lessons to have. Kate even said that using authentic activities would mean fooling students: they will never do activities such as designing a park for real. The only real thing is the test in the end. Marion thought it would be impossible for students to learn from activities that resemble what people do in realworld contexts. A palaeontologist, for example, already has the knowledge the students still have to acquire, so that a palaeontologist's questions and activities necessarily have to be essentially different from the questions and activities of students learning in a palaeontology context.

With regards to the structure of the lessons, two main dissimilarities with the formal design principles catch the eye. First, four teachers chose to employ multiple contexts within one lesson or lesson sequence, ranging from three (Kate and Thomas) to six or more (David and Vera), 
instead of focusing on just one. Although in none of the cases this was an explicit rule-of-thumb, we can understand why these teachers chose to use multiple contexts within one lesson when we look at the intended lesson outcomes. David wanted to show the general applicability of a biological idea to his students, and to amaze them by using a large variety of stories and images. Vera wanted to make biology relevant for students themselves, so she let her students choose their own contexts, apart from the context that was personally relevant to her. Thomas wanted to enjoy himself while having his students enjoy themselves, and, as he said, both he and his students liked to exchange tall stories, the more the better. Kate, on the other hand, led her students through different contexts at different organizational levels to deeper conceptual understanding. A second difference with the formal lesson structure is that not every teacher started the lesson with a vivid introduction to the context. In this regard Kate and David had a comparable strategy: they began with highlighting a question central to biology, after which they illustrated the answer to this question by using different contexts. Kate explicitly stepped away from the principle that the students' learning process should start from a context and then proceed towards an abstract concept that can be applied in a new context, because she thought that students first need to have the tools (concepts) needed to approach a situation from a biological perspective.

In conclusion, when designing context-based lessons the teachers in this study mainly aimed at activating and motivating students, which is in accordance with the findings by Platteel (2010) in her study of eleven Dutch native language (L1) teachers who designed context-based lessons. Our teachers also, though to a lesser extent, aimed at enlarging conceptual understanding. Only the experienced designers of context-based lessons (David \& Vera) aimed at increasing the relevance of their teaching, enhancing conceptual coherence, and having students learn about specific contexts and specific ways of thinking and acting while stimulating their personal development.

Deleted: ๆ

Implications and limitations $\uparrow$

This section is divided into two parts. We will first discuss implications for the concept of rules-of-thumb in relation to the concept of teachers' practical the concept of teachers practical
knowledge. Then, implications for knowledge. Then, implications for
curriculum innovation will be considered. 


\section{Teachers' practical knowledge and their use of rules-of-thumb}

The descriptive studies into lesson design by teachers in the 1970s have made clear that teachers' decision making during lesson design should not be considered a process of generating and rationally weighing alternatives (Shavelson \& Stern, 1981). Our study offers an alternative by suggesting that biology teachers' practical knowledge guides their educational decision making during lesson design via the use of personal rules-of-thumb. This finding is in line with conclusions from more general research into decision making in realistic settings, of which a main representative is Gigerenzer (Gigerenzer, 2008; Gigerenzer \& Goldstein, 1996). Following Simon (1972), Gigerenzer stresses the fact that people's rationality is bounded, which means that our decision making is constrained by the availability of time and means and by the limitations of our information processing capacity. Under these circumstances decision making is greatly influenced by heuristics (rules-of-thumb), for which Gigerenzer gives examples from different fields such as sports and medicine. Our study suggests that rules-of-thumb play a similar role in educational decision making by teachers, and that these rules-of-thumb can be viewed as that part of teachers' practical knowledge that has a direct effect on educational decision making.

One characteristic of such "rules-of-thumb" deserves further attention. The rules-ofthumb used by the teachers in this study appeared to be strongly related to intended lesson outcomes and broader teaching goals, as we discussed before. David wanted to include many different contexts in his lesson, because he aimed at showing the general applicability of a biological idea, and Vera used personal stories in her lesson because she wanted her students to understand the relevance of biology to their personal lives. Similarly, many rules-of-thumb (such as 'start the lesson by giving meaning to the concepts, using material from students' own lives' (Kate)) could be split up into different levels, one an outcome of the other. If we take this a little further, it is conceivable that the whole of teachers' rules-of-thumb, related to particular classes and subjects, can be represented by a hierarchy of rules, with the intended outcomes and broader goals at the top and the means at the bottom. These rules-of-thumb, on different levels of
Deleted: Five years ago, Hashweh (2005) called for more research into the relation between teachers' practical knowledge and their educational design activities. The outcomes of our study will hopefully contribute to an increased understanding of this relationship. \begin{tabular}{l} 
Deleted: ๆ \\
However, some remarks about this concept \\
seem in place here. First, as mentioned in \\
the Results section, the validity of the \\
rules-of-thumb presented in this study has \\
only been demonstrated for particular \\
classes, levels and topics, although \\
teachers' personal remarks suggest a wider \\
validity. As teachers' practical knowledge is \\
generally seen as very personal and \\
context-bound (Van Driel et al., 2001), the \\
use of certain rules-of-thumb is also \\
expected to vary across topics and groups \\
of students. \\
Second, \\
\hline Deleted: , for example, \\
\hline Deleted: seem \\
\hline Deleted: $M$
\end{tabular} 
abstraction, would be linked together through the questions of 'how' to reach a goal, or 'why' to

do something a certain way

Now, the question is how these rules-of-thumb relate to other conceptualisations of teacher practical knowledge. We will argue that rules-of-thumb are that part of a teacher's practical knowledge that directly guides this teacher's decisions. We believe that in order to study the dialectical relations between teachers knowledge and teacher planning, for which Hashweh (2005) did an urgent appeal, one should focus on that part of a teacher's knowledge that directly guides a teacher's actions. This does not mean that a teacher's knowledge does not encompass more. A teacher's rules-of-thumb are part of, and influenced by, a larger knowledge base of teaching. Since the mid-80s, many studies have been dedicated to the unravelling of the composites of this knowledge base of teaching. In the field of science education, many of such studies focused on studying teachers' Pedagogical Content Knowledge (PCK). The concept of PCK has been introduced by Shulman $(1986,1987)$ as an element of the knowledge base of teaching (which, apart from PCK, includes content knowledge, general pedagogical knowledge, curriculum knowledge, knowledge of learners, knowledge of educational contexts and knowledge of educational ends). In Shulman's words, PCK “represents the blending of content and pedagogy into an understanding of how particular topics, problems, or issues are organized, represented, and adapted to the diverse interests and abilities of learners, and presented for instruction" (Shulman, 1987, p. 8). In many studies PCK is identified as consisting of different subcategories of knowledge (e.g. Magnusson, Krajcik, \& Borko, 1999), and many studies aim at recovering the content of these subcategories in the study of particular teachers. The study of PCK in this manner can be valuable to identify common patterns in the practical knowledge of individual teachers, which may help furthering our understanding of teacher knowledge and building a framework for helping teachers to develop their pedagogical repertoire. Teachers, however, use all the components of their knowledge in an integrated fashion when planning and implementing their lessons (Abell, 2008). As our study shows, when teachers explain why they

\section{Deleted:}

Deleted: This idea of a hierarchy of goals has been elaborated by cognitive psychologists, and has been clearly described by Carver and Scheier (Carver \& Scheier, 2001; Kruglanski, Shah, Fishbach, Chun, \& Sleeth-Keppler, 2005)(2001) for instance, but its applicability to the study of teacher knowledge still needs to be investigated. 


\section{Implications for curriculum innovation}

In this study teachers have designed lessons in the context of a curriculum innovation. It has long

been known that teachers generally do not implement an innovative curriculum in exactly the way

take certain decisions when planning their lessons, they do this by using rules-of-thumb: rules that integrate parts of their pedagogical content knowledge that are relevant for that specific moment, those specific students, that specific topic, that specific context in which they design their lesson.

A teacher's practical knowledge is known to be person- and context-bound (Van Driel et al., 2001), and this is particularly true for the sets of rules-of-thumb that we identified in this study. A particular context will trigger particular rules-of-thumb. Also, contextual conditions can be translated into rules-of-thumb. An example is the frequently occurring rule to use a context that matches the concepts to be learnt, as dictated by the longer-term plan. This automatically points to a possible limitation of this study: Although the teachers confirmed they recognized themselves and their teaching styles in our case descriptions and in the rules-of-thumb we identified, we do not know to what extent these subsets of rules-of-thumb are representative for these teachers' practice. What's more, the teachers in this study have been asked to design an innovative lesson, with the exception of David and Vera, who were already used to designing context-based lessons. We have not studied which rules-of-thumb the other four teachers use on a regular basis, which of those would be easily replaced by formal design principles, and which are most resistant to change. Follow-up studies are needed to answer these questions. Following teachers through the design of a greater number of more diversified lessons would enable us to increase the validity of the outcomes, and possibly to construct a more complete system of hierarchically related rules-of-thumb, after which questions about the stability, coherence and diversity of such systems could be addressed.
Deleted: Third, the case of Thomas seems to suggest there might be a difference in the use of rules-of-thumb between beginning and experienced teachers, especially in the linkage of rulesof-thumb with intended lesson outcomes. However reasonable this sounds, these observations are based on only one case, and more research is needed before this can be confirmed. 9

Fourth, the teachers in this study have been asked to design an innovative lesson, with the exception of David and Vera, who were already used to designing contextbased lessons. We have not studied which rules-of-thumb the other four teachers use on a regular basis, which of those would be easily replaced by formal design principles, and which are most resistant to change. Follow-up studies are needed to answer these questions. Following teachers through the design of a greater number of more diversified lessons would enable us to increase the validity of the outcomes, and possibly to construct a more complete system of hierarchically related rules-ofthumb, after which questions about the stability, coherence and diversity of such systems could be addressed. $\|$ 
it had originally been envisioned, and that their interpretations and adaptations are crucial in determining how an innovation is enacted in the classroom (Van den Akker, 2003; Van Driel et al., 2001). Therefore, it has been strongly recommended to take teachers' knowledge and beliefs into account when innovating a curriculum (Borko \& Putnam, 1996; Fullan, 2004). This is, however, not straightforward. We know that the relation between teacher cognitions and teacher behaviour is not always consistent (Mathijsen, 2007). Teacher practical knowledge is also known to remain largely implicit (Van Driel et al., 2001). It is therefore needed to elicit that part of knowledge that actually guides teachers' actions. Focusing on teachers' rules of thumb by studying their lesson design processes seems to be promising, not only because rules-of-thumb appear to be strongly consistent with teachers' actions, but also because it is expected that an important part of the interpretation and translation of innovative ideas takes place during the design of lessons (Hashweh, 2005).

The results of our study indicate that a teacher's objectives, through the use of rules-ofthumb, determine which formal design principles are adopted and which are not. Teachers' aim of motivating students, for example, conflicted, in their opinion, with the formal principle of using authentic contexts, and the aims of covering the concepts as stated in the longer-term plan and presenting the concepts within a clear framework conflicted with the formal ideal of making $\underline{\text { connections between different biological themes within one context. }}$

Our findings could have been influenced by the fact that the teachers had not received any professional support in designing context-based lessons, apart from the experiences some of them had before the start of this study. Although this was a conscious choice, related to the aims of this study (many teachers in The Netherlands will not receive professional support in designing context-based lessons and are nonetheless expected to enact the new curriculum in future), it will certainly have had its effect on the outcomes, and we encourage the development of professional development programs to support biology teachers in their design of contextbased lessons. How, then, could the findings of this study inform the design of such programs?
Deleted: Teachers' lesson design processes have seldom been considered within the context of curriculum innovation, although it can be

Deleted: that it is exactly during lesson design 


\section{References}

Abell, S. (2008). Twenty Years Later: Does pedagogical content knowledge remain a useful idea? International Journal of Science Education, 30(10), 1405-1416.

Aikenhead, G. (2007). Humanistic perspectives in the science curriculum. In S. K. Abell \& N. G. Lederman (Eds.), Handbook of research on science education. (pp. 881-910). Mahwah, New Jersey: Lawrence Erlbaum Associates.

We would recommend such a design to build upon knowledge and beliefs of the teachers who participate (Verloop, Van Driel, \& Meijer, 2001). This could be achieved by having the teachers design a lesson while thinking aloud, which will help to make their current rules-ofthumb explicit, and to repeat this in several cycles of design, implementation and reflection. A first group meeting could be dedicated to an explicit discussion of the participants' personal rules-of-thumb in the perspective of the formal objectives and design principles, where the main focus should be the objectives, because these appeared to be very influential. Such a discussion could be facilitated by the use of illustrative curriculum materials. Later in the program, when teachers are working on the design and implementation of lessons, rules of thumb or heuristics could be regularly identified and referred to. If a teacher chooses not to implement certain innovative principles, this could have different causes: the teacher does not have the same objectives as those underlying the innovation (after which a further discussion of the importance of different educative goals is to follow), the teacher does not believe that innovative principles will lead to the proposed objectives, or the teacher does not believe to be able to implement the principles as proposed. In those cases, the teachers could be supported on demand by providing them with tools, having them exchange good practices and providing them with further exemplary teaching materials. \begin{tabular}{l} 
Deleted: and understand how to build \\
upon teachers' knowledge and beliefs when \\
implementing a curriculum innovation. The \\
outcomes illustrate the necessity to \\
consider teachers' personal practical \\
knowledge when working on educational \\
innovation, and illuminate possible \\
tensions between formal design principles \\
and personal rules-of-thumb in the case of \\
context-based biology education. 9 \\
It seems that teachers, when designing \\
lessons, take their decisions according to \\
the outcomes they want to produce. If a \\
formal design principle does not comply \\
with an intended outcome, the principle \\
will be discarded. This does not necessarily \\
mean that teachers' practical knowledge \\
should be the norm, for it is possible that \\
teachers are not aware of the importance \\
of these innovative objectives. Therefore, \\
when communicating with teachers, two \\
separate questions should be addressed: \\
'are the proposed goals important?' And 'is \\
the innovation expected to reach these \\
goals?' \\
I \\
I \\
\hline Formatted: English (U.S.) \\
Formatted: English (U.S.) \\
Formatted: English (U.K.) \\
\hline
\end{tabular} 
Bennett, J., Grasel, C., Parchmann, I., \& Waddington, D. (2005). Context-based and conventional approaches to teaching chemistry: Comparing teachers. International Journal of Science Education, 27(13), 1521-1547

Bennett, J., Lubben, F., \& Hogarth, S. (2007). Bringing science to life: A synthesis of the research evidence on the effects of context-based and STS approaches to science teaching. Science Education, 91(3), 347-370.

Boersma, K. T., Van Graft, A., Harteveld, A., De Hullu, E., De Knecht-van Eekelen, A., Mazereeuw, M., et al. (2007). Leerlijn biologie van 4 tot 18 jaar [learning trajectory biology age 4 till 18 ]. Utrecht: CVBO.

Borko, H., \& Putnam, R. (1996). Learning to teach. In D.C. Berliner \& R.C. Calfee (Eds), Handbook of educational psychology (Vol. 2, pp. 673-708). New York: Macmillan.

Bulte, A. M. W., Westbroek, H. B., de Jong, O., \& Pilot, A. (2006). A research approach to designing chemistry education using authentic practices as contexts. International Journal of Sience Education, 28(9), 1063-1086.

Clark, C. M., \& Dunn, S. (1991). Second-generation research on teachers' planning, intentions, and routines. In H.C. Waxman \& H.J. Walberg (Eds), Effective Teaching: Current Research, 183201. Berkeley: McCutchan.

Clark, C. M., \& Peterson, P. L. (1986). Teachers' thought processes. In M. C. Wittrock (Ed.), Handbook of research on teaching (3rd edition) (pp. 255-296). New York: MacMillan.

Doyle, W., \& Ponder, G. (1977). The practicality ethic in teacher decision-making. Interchange, $8(3), 1-12$

Elbaz, F. (1983). Teacher thinking: A study of practical knowledge. London: Croom Helm.

Feldman, A. (2000). Decision making in the practical domain: A model of practical conceptual change. Science Education, 84(5), 606-623.

Fullan, M. (2007). The new meaning of educational change (4th ed.). New York: Teachers College Press. 
Gigerenzer, G. (2008). Rationality for mortals: How people cope with uncertainty: Oxford University Press, USA.

Gigerenzer, G., \& Goldstein, D. (1996). Reasoning the fast and frugal way: Models of bounded rationality. Psychological review, 103(4), 650-669.

Gilbert, J. (2006). On the nature of "context" in chemical education. International Journal of Science Education, 28(9), 957-976.

Glynn, S., \& Koballa, T. R. (2005). The contextual teaching and learning instructional approach. In R. E. Yager (Ed.), Exemplary science: best practices in professional development. (pp. 75-84). Arlington, VA: National Science Teachers Association Press.

Goedhart, M. (2004). Contexten en concepten: een nadere analyse [Contexts and concepts: a further analysis]. NVOX, 29, 186-190.

Hashweh, M. Z. (2005). Teacher pedagogical constructions: A reconfiguration of pedagogical content knowledge. Teachers and Teaching, 11(3), 273-292.

Janssen, F., Veldman, I., \& Van Tartwijk, J. (2008). Modelgestuurd leren van je succes, praktisch uitgewerkt voor de biologiedidactiek [Model based learning from success: Practical elaboration for the pedagogy of biology]. VELON Tijdschrift voor Lerarenopleiders, 29(2), 4-13.

KNAW. (2003). Biologieonderwijs: een vitaal belang [Biology education: A vital importance]. Amsterdam: Koninklijke Nederlandse Akademie van Wetenschappen.

Kortland, J. (2007). Context-based science curricula: Exploring the didactical friction between context and science content, ESERA. Malmö, Sweden.

Krajcik, J., McNeill, K. L., \& Reiser, B. J. (2008). Learning-goals-driven design model: Developing curriculum materials that align with national standards and incorporate projectbased pedagogy. Science Education, 92(1), 1-32.

Levin, B., \& He, Y. (2008). Investigating the content and sources of teacher candidates' personal practical theories (PPTs). Journal of Teacher Education, 59(1), 55-68. 
Lijnse, P. (2007). De nieuwe kleren van de concept-contextbenadering [The new clothes of the concept-context approach]. NVOX, 32(5), 241-246.

Magnusson, S., Krajcik, J., \& Borko, H. (1999). Nature, sources and development of pedagogical content knowledge for science teaching. In Examining Pedagogical Content Knowledge: The Construct and Its Implications for Science Education (pp. 95-132). Dordrecht: Kluwer Academic Publishers.

Mathijsen, I. (2007). Denken en handelen van docenten. Utrecht University, Utrecht.

Meijer, P. (1999). Teachers' practical knowledge. Teaching reading comprehension in secondary education. Leiden: Leiden University

Miles, M., \& Huberman, A. (1994). Qualitative data analysis: An expanded sourcebook. Thousand Oaks: Sage Publications.

Peters, J. J., \& Beijaard, D. (1983). Onderzoek naar onderwijsplanning en -realisatie door ervaren leerkrachten: Naar een handelingstheorie van het onderwijzen [Research into educational planning and realization by experienced teachers: Towards an action theory of teaching]. Info, 14(5), 255-304.

Pilot, A., \& Bulte, A. M. W. (2006). The use of "contexts" as a challenge for the chemistry curriculum: Its successes and the need for further development and understanding. International Journal of Sience Education, 28(9), 1087-1112.

Platteel, T. (2010). Knowledge development of secondary school L1 teachers on concept-context rich education in an action-research setting. Leiden University, Leiden.

Sanchez, G., \& Valcarcel, M. V. (1999). Science teachers' views and practices in planning for teaching. Journal of Research in Science Teaching, 36(4), 493-513.

Schalk, H., \& De Hullu, E. (2007, February 17). Contexten zijn geen opleukertje [Contexts are no seasoners]. Bionieuns.

Scott, P., Asoko, H., \& Leach, J. (2007). Student conceptions and conceptual learning in science. In S. K. Abell \& N. G. Lederman (Eds.), Handbook of research on science education (pp. 31-56). Mahwah, New Jersey: Lawrence Erlbaum Associates. 
Shavelson, R. (1973). What is the basic teaching skill? Journal of Teacher Education, 14, 144-151.

Shavelson, R., \& Stern, P. (1981). Research on teachers' pedagogical thoughts, judgments, decisions, and behavior. Review of Educational Research, 51(4), 455-498.

Shulman, L. (1986). Those who understand: Knowledge growth in teaching. Educational Researcher, 15(2), 4-14.

Shulman, L. (1987). Knowledge and teaching. Harvard Educational Review, 57(1), 1-22.

Simon, H. A. (1972). Theories of Bounded Rationality. Decision and Organization, 1, 161-176.

Taasoobshirazi, G., \& Carr, M. (2008). A review and critique of context-based physics instruction and assessment. Educational Research Review, 3, 155-167.

Van Berkel, B. (2005). The structure of current school chemistry-a quest for conditions for escape. Utrecht University, Utrecht.

Van den Akker, J. (2003). Curriculum perspectives: An introduction. In J. Van den Akker, Hameyer, U., Kuiper, W. (Ed.), Curriculum landscapes and trends (pp. 1-10). Dordrecht: Kluwer Academic Publishers.

Van den Oever, L. (2007, April 7). Contexten geven actualiteit, relevantie en samenhang [Contexts give current interest, relevance and coherence]. Bionieuws.

Van Driel, J. H., Beijaard, D., \& Verloop, N. (2001). Professional development and reform in science education: The role of teachers' practical knowledge. Journal of Research in Science Teaching, 38(2), 137-158.

Verloop, N., Van Driel, J., \& Meijer, P. (2001). Teacher knowledge and the knowledge base of teaching. International Journal of Educational Research, 35(5), 441-461.

Vermaat, H. (2007). Nut en onnut van contexten in het (scheikunde)onderwijs [sense and nonsense of contexts in (chemistry) education]. NVOX, 31(8).

Wolter, H., \& Van Woerkom, R. (2007). De context in de praktijk. Een benadering van het context-conceptcurriculum in het biologieonderwijs [The context in practice. An approach of the concept-context curriculum in biology education]. NVOX, 32(3). 
Yinger, R. J., \& Hendricks-Lee, M. S. (1994). Approaches to teacher planning. In L. W. Anderson (Ed.), International encyclopaedia of teaching and teacher education (pp. 6031-6035). Cambridge: Cambridge University Press.

Zeidler, D. L., Sadler, T. D., Simmons, M. L., \& Howes, E. V. (2005). Beyond STS: A researchbased framework for socioscientific issues education. Science Education, 89(3). 
The topic of the lesson will be biodiversity Context taken into consideration, but rejected: holiday

$$
\text { Context taken into consideration, but rejected: }
$$
recreation

Context taken into consideration, but rejected: investigate soil specimens with many, and with few different animal species

Context taken into consideration, but not chosen: compost heap

Context taken into consideration, and chosen: students' own house

Student activity: draw your own house

$\begin{aligned} \text { - Accoses } & \text { lives } \\ \text { - It } & \text { It }\end{aligned}$

- It fits the concept of "habitat" nicely

The assignment is worked out on a worksheet
successful in the past. The worksheet coaches the students through their thinking processes, because the teacher cannot coach all students at the same time.

Second context chosen: the house of an animal - Apply the concept "habitat"

- Thinking from the perspective of the organism is in accordance with the biological way of thinking, which all revolves around the issue how animals manage to survive.

Students are assigned a specific organism, they cannot choose for themselves

- It would be fun to have them choose for themselves, but then they would choose their pets, who live in a house, instead of in a park.

- Many different organisms are needed in order to end up with the concept of "biodiversity"

All animals chosen live in the park nearby school Students know this park, and would be able to encounter these animals there, which would help them recognize the biology in the real world.

Students write the name of their animal on a note, and if possible stick it in their natural habitat on the map of a park

- Enables students to understand the link between the concept of habitat and the concept of biodiversity.

- Motivates students to think about nature development.

A final assignment in which students practice the use of the concept of biodiversity

Two lessons, instead of one

The lesson as designed does not fit in one session. Having two sessions has the additional advantage of making it more likely that students gain lasting knowledge.

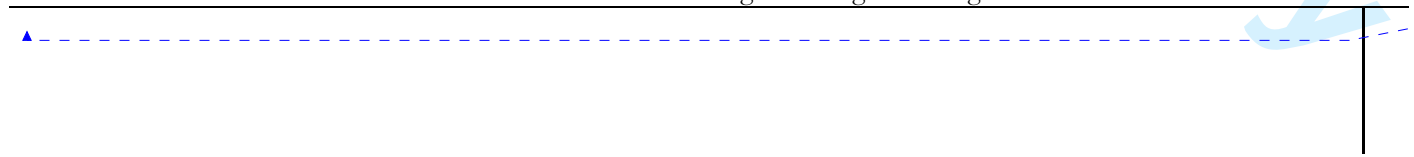


Figures and Tables

Figure 1: Formal design principles

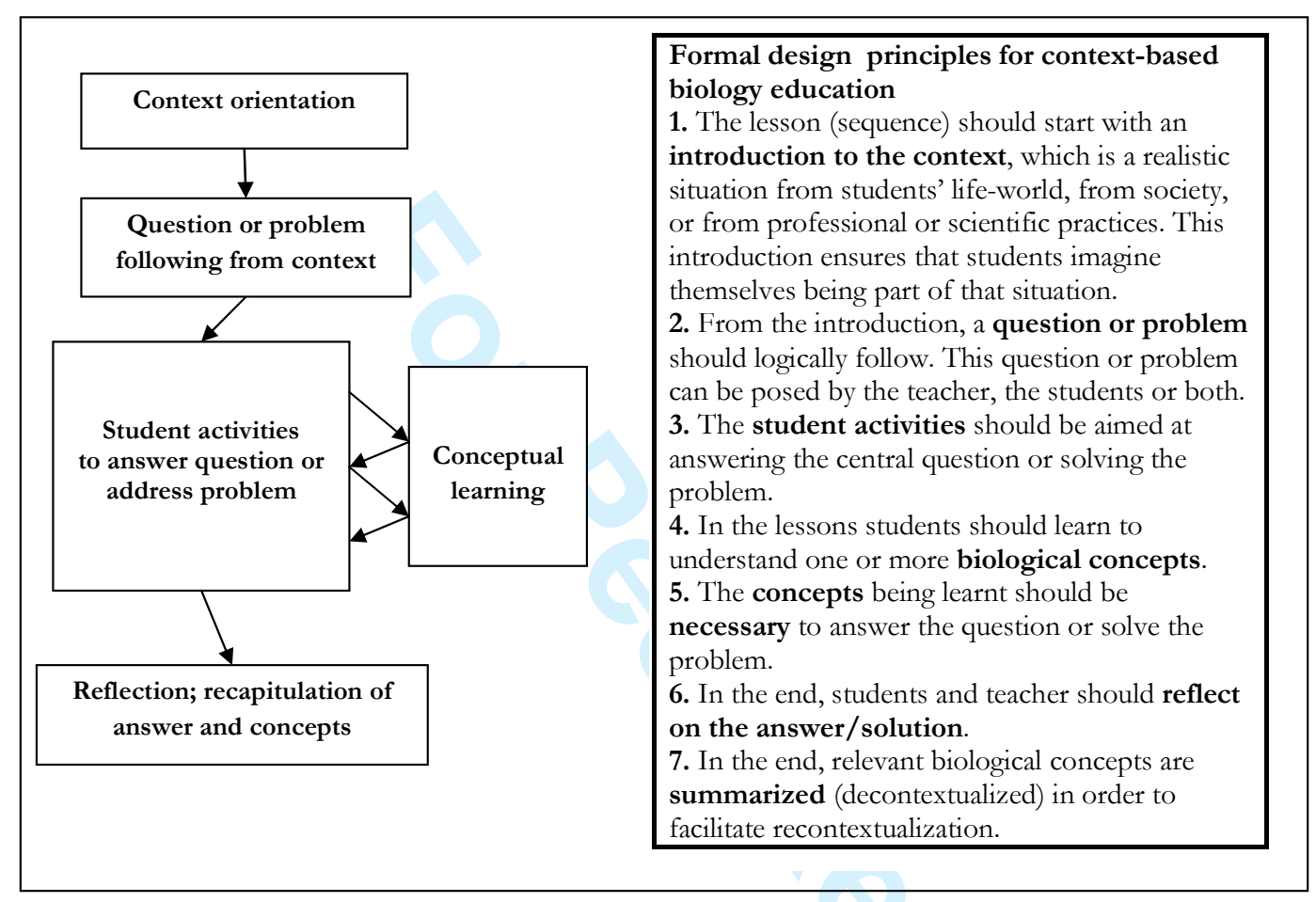


Table 1: Participant characteristics

\begin{tabular}{lllllll}
\hline Teacher & Kate & Richard & Marion & Thomas & David & Vera \\
\hline $\begin{array}{l}\text { Teaching experience } \\
\text { (yrs) }\end{array}$ & 8 & 6 & 13 & 1 & 22 & 4 \\
$\begin{array}{l}\text { Experience in designing } \\
\text { context-based lessons }\end{array}$ & None & None & Minor & None & 3 yrs & 3 yrs \\
$\begin{array}{l}\text { Grade level } \\
\begin{array}{l}\text { Upper/lower secondary } \\
\text { education }\end{array}\end{array}$ & Power & Gse & Pue & Gse & Pue & Pve \\
\end{tabular}

${ }^{1}$ pue $=$ pre-university education, gse $=$ general secondary education, pve $=$ pre-vocational education 
Table 2: The teachers' rules-of-thumb and intended outcomes

\begin{tabular}{|c|c|}
\hline$\underline{\text { Kate }}$ & \\
\hline Rule-of-thumb & Intended outcome \\
\hline $\begin{array}{l}\text { Start the lesson by giving meaning to the concepts, } \\
\text { using students' own daily life }\end{array}$ & $\begin{array}{l}\text { Students learn they are organisms that are part of } \\
\text { the science of biology } \\
\text { Students are able to give meaning to the concept }\end{array}$ \\
\hline$\underline{\text { Use well-structured assignments }}$ & $\underline{\text { Students think at a higher level }}$ \\
\hline $\begin{array}{l}\text { Let students learn the theory first, before applying it } \\
\text { in a context }\end{array}$ & $\begin{array}{l}\text { Students acquire the biological thinking tools } \\
\text { needed to interpret the context }\end{array}$ \\
\hline Use the textbook & $\begin{array}{l}\text { Students feel secure, and are able to connect the } \\
\text { lesson to the theory in the book }\end{array}$ \\
\hline$\underline{\text { Use creative activities }}$ & $\underline{\text { Students are motivated }}$ \\
\hline Start at organism level & $\begin{array}{l}\text { Students learn to think "biologically" by } \\
\text { wondering how organisms succeed in staying } \\
\text { alive }\end{array}$ \\
\hline Use the concepts in multiple situations & $\begin{array}{l}\text { Students learn to use the concepts in different } \\
\text { situations }\end{array}$ \\
\hline Richard & \\
\hline$\underline{\text { Rule-of-thumb }}$ & Intended outcome \\
\hline The context matches the entire concept & Students get a an idea of the concept as a whole \\
\hline$\underline{\text { Use a simple context }}$ & $\begin{array}{l}\text { Students easily understand and remember the } \\
\underline{\text { context }}\end{array}$ \\
\hline $\begin{array}{l}\text { If we are talking about the human body the focus is } \\
\text { on processes in students' own bodies }\end{array}$ & $\underline{\text { Students imagine how their own bodies work }}$ \\
\hline Do not use medical contexts & $\begin{array}{l}\text { Attention is concentrated on the positive facts: } \\
\text { the beauty of the complexity of the body when it } \\
\text { goes right, instead of wrong. }\end{array}$ \\
\hline$\underline{\text { Use an appealing context }}$ & Students pay attention to the lesson \\
\hline $\begin{array}{l}\text { Give students examples that help them to } \\
\text { remember facts }\end{array}$ & Students remember the facts they learn \\
\hline Use a variety of student activities & $\underline{\text { Students' concentration levels are high }}$ \\
\hline Have students find out the facts themselves & Students acquire lasting knowledge \\
\hline $\begin{array}{l}\text { The teacher gives a structured overview of the } \\
\text { biological concepts }\end{array}$ & $\begin{array}{l}\text { This helps students to build a conceptual } \\
\text { network }\end{array}$ \\
\hline$\underline{\text { Marion }}$ & 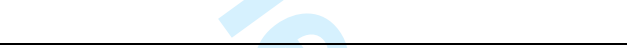 \\
\hline Rule-of-thumb & Intended outcome \\
\hline Use a context that students can relate to & $\begin{array}{l}\text { Students give meaning to the concepts } \\
\text { Students remember the concepts }\end{array}$ \\
\hline$\underline{\text { Use a variety of student activities }}$ & $\begin{array}{l}\text { Students are motivated } \\
\underline{\text { Students are active }}\end{array}$ \\
\hline $\begin{array}{l}\text { Use structured assignments } \\
\text { Use the media (television, internet) }\end{array}$ & \\
\hline Thomas & \\
\hline Rule-of-thumb & Intended outcome \\
\hline $\begin{array}{l}\text { Concepts should be presented in a structured } \\
\text { fashion. The context should neatly fit the concepts: } \\
\text { avoid contexts in which too many biological } \\
\text { concepts play a role }\end{array}$ & Students understand the concepts \\
\hline $\begin{array}{l}\text { The context appeals to teacher and students } \\
\text { The student activities are "fun" to do }\end{array}$ & $\begin{array}{l}\text { Both students and teacher are having a good time } \\
\text { Students have fun }\end{array}$ \\
\hline
\end{tabular}


The use of clichés is avoided

Students have the opportunity to move around

during the lesson

There is room for students to make their own

contribution to the lesson

$\underline{\text { Use newspaper articles }} \quad \underline{\text { Students see the relevance of biology to daily life }}$

Use video material Students enjoy class

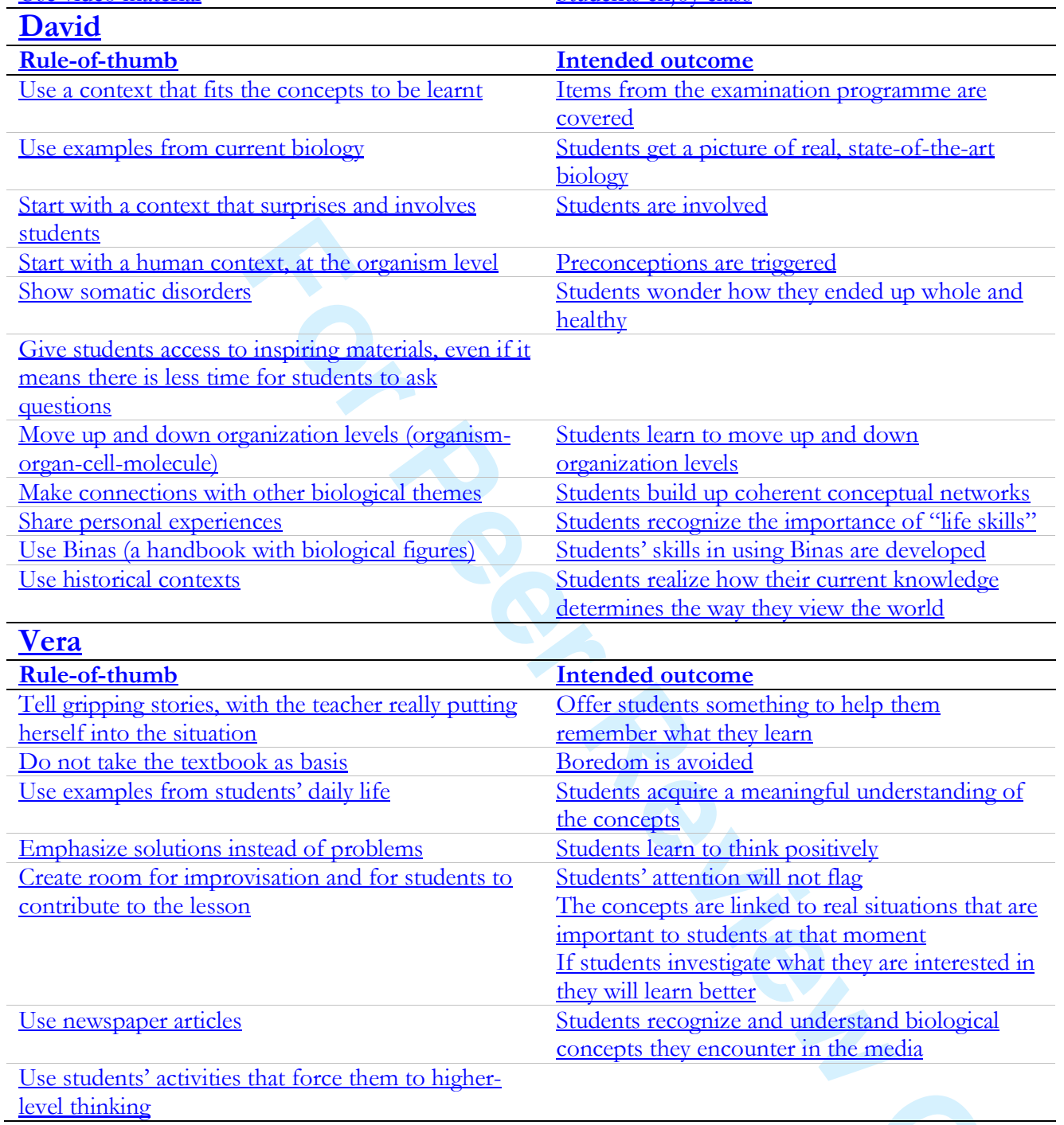




\section{Page 19: [1] Deleted}

wieringan

10/6/2010 4:04:00 PM

Each teachers' individual set of rules-of-thumb seem to be a good representation of the manner in which these teachers' personal practical theories influence their decision making while designing lessons, as has been confirmed by the teachers themselves. In summary:

Kate's efforts were all focused on furthering students' understanding of biological concepts, with the ultimate aim of having students think like biologists when considering real-world situations. She worked towards these goals by giving her lessons the following properties: start from the concepts, use the textbook, and use examples from the students' own lives to give meaning to the biological concepts.

Richard mainly focused on activating his students, and giving them tools to help them to remember the lesson content. It was also very important for him that students were given a positive image of biology. Important rules-of-thumb were: use a simple and appealing context, stimulate students to find knowledge themselves, while offering tools that help students to remember the facts.

Marion's main educational principle was not defined at the level of one lesson, but at the level of a longer sequence of lessons. Her main rule-of-thumb implied offering her students a large variety of learning activities, in order to cater for students with different learning styles. She considered context-based education another new asset within her repertoire.

Thomas seemed to be focused mainly on making enjoyable and original lessons and having his students learn the concepts from the book. There were no strong links between his rules-of-thumb and intended lesson outcomes, which might be explained by the fact that he was still in his first year of teaching.

David's lesson had many objectives: having his students develop a firm understanding of the biological concepts while experiencing feelings of wonder, becoming more 
1

2

3

4

5

10

11

12

13

14

15

16

17

18

19

20

21

22

23

24

25

26

27

28

29

30

31

32

33

34

35

36

37

38

39

40

41

42

43

44

45

46

47

48

49

50

51

52

53

54

55

56

57

58

59

60

competent in using biological handbooks, understanding how science affects society and their view of the world, and realizing how they personally relate to the scientific story while at the same time learning about specific contexts. During the design of the lesson David demonstrated the use of numerous rules-of-thumb, which he had built up during his long experience as a teacher and developer of context-based lessons. These were not fully reflected in this particular lesson, which was one long, though dynamic, lecture.

Vera was the only teacher who did not determine the concepts to be learnt beforehand. She considered it more important for her students to realize the importance of the biological domain of genetics for society and for their personal life, and left her students fairly free to determine what they wanted to investigate.

URL: http://mc.manuscriptcentral.com/tsed Email: editor_ijse@hotmail.co.uk 